\title{
Persepsi Tokoh Ulama dan Adat Melayu Jambi Sekitar Kontroversi Penafsiran Kata Awliyâ'dalam QS. Al-Ma'idah: 51
}

(The Perception of Jambi Malay Cleric and Traditional Leaders about the Controversy on the Interpretation of the Word Awliya' in QS. Al-Ma'idah: 51)

\author{
Ahmad Syukri \\ UIN Sulthan Thaha Saifuddin Jambi, Indonesia \\ ahmadsyukri@uinjambi.ac.id
}

DOI: $10.29240 /$ alquds.v5i2.2080

Submitted: 2021-07-03 | Revised: 2021-08-20 | Accepted: 2021-08-31

\begin{abstract}
This article aims at uncovering the background behind controversy around Qur'anic interpretation of al-Ma'idah/5: 51 and how Muslim scholars and Malay traditional leaders of Jambi respond and view that issue. The interpretation on word awliyâ' became viral in social media a few years ago, particularly when it related to prohibiton to elect public leader whose religion differed from his/her majority constituents. This research was conducted through qualitative method by using sociological approach in the frame of transformative Islam. Data were collected through observation, interview dan documentation. This research found that the controversy happened due to different interpretation and perception among Muslim scholars on the word awliyâ'. Such different interpretation and perception subsequently brought about a variety of responses and perpectives among Muslim scholars and traditional leaders of Jambi. Shortly, interpretation of a word in Qur'anic verse through textual and contextual method becomes a dominant trigger for the existence of such different interpretation and perception. Besides, a traditional root which is sociologically inherent in Malay community of Jambi takes part in determining attitude to which direction their tendencies on this controversy are.
\end{abstract}

Keywords: controversy of interpretation; perception; muslim scholars; Malay traditional leaders

Abstrak. Artikel ini bertujuan untuk mengungkap latar belakang terjadinya kontroversi
penafsiran QS. al-Ma'idah/5: 51 dan bagaimana persepsi tokoh ulama dan adat Melayu
Jambi. Penafsiran kata awliyâ'dalam ayat tersebut sempat viral di media sosial beberapa
waktu yang lalu, terutama ketika dikaitkan dengan larangan memilih pemimpin publik
yang tidak seiman dengan mayoritas konstituennya. Penelitian ini menggunakan metode
kualitatif dengan pendekatan sosiologis dalam bingkai Islam transformatif. Pengumpulan
data dilakukan melalui teknik observasi, wawancara dan dokumentasi. Penelitian ini
menemukan bahwa kontroversi muncul karena adanya perbedaan penafsiran dan 
pemahaman di kalangan para ulama menyangkut kata awliyấ. Perbedaan pandangan ini berikutnya menimbulkan persepsi yang bervariasi di kalangan tokoh agama dan adat Jambi. Walhasil, penafsiran potongan ayat Al-Qur'an yang dilakukan secara tekstual dan kontekstual menjadi pemicu dominan terjadinya perbedaan penafsiran dan pemahaman tersebut. Selain itu, akar tradisi yang secara sosiologis telah mendarah daging dalam masyarakat Melayu Jambi ikut berperan dalam menentukan sikap ke arah mana keberpihakan mereka menyangkut kontroversi ini berada.

Kata Kunci: kontroversi penafsiran, persepsi, tokoh ulama, tokoh adat

\section{Pendahuluan}

Seperti dimaklumi bahwa ilmu tafsir merupakan salah satu disiplin ilmu yang sangat penting dalam menggali makna yang terkandung dalam kitab suci AlQur'an, karena ia berisi seperangkat aturan dan norma yang dapat membantu seseorang yang ingin menelusuri dan memahami pesan yang disampaikan AlQur'an. Seseorang yang tidak mengetahui tafsir dari suatu ayat dapat dipastikan akan jatuh pada kekeliruan pemahaman dan tidak jarang menyesatkan. Seseorang yang ingin menafsirkan Al-Qur'an perlu dibekali dengan seperangkat instrumen keilmuan, terutama yang berkaitan dengan penguasaan bahasa Arab selain ilmu pendukung seperti sejarah Al-Qur'an, konteks sosiologis dan antropologis masyarakat di mana Al-Qur'an diturunkan. Ringkasnya, penafsiran Al-Qur'an baru dianggap memadai apabila penggalian dan penelusuran makna ayat mengacu kepada teks dan konteksnya.

Perbedaan persepsi acapkali terjadi ketika seseorang menafsirkan AlQur'an hanya merujuk pada salah satu makna baik secara tekstual maupun kontekstual. Meskipun, harus diakui, tidak jarang dengan menggunakan pendekatan tekstual makna ayat sudah dapat dipahami pembaca. Sementara itu, ditemukan pula ayat yang secara kontekstual mengandung makna lebih dari satu sehingga memberikan peluang kepada pembaca untuk memilih salah satu makna, misalnya penafsiran kata awliyâ' yang terdapat dalam surat al-Ma'idah/5: 51 . Penafsiran kata awliyâ' menjadi penting untuk diangkat ketika berbicara dalam ranah sosial politik. Boleh dikatakan hampir pada setiap menjelang pemilihan presiden (pilpres) dan pemilihan kepala daerah (pilkada) isu politik identitas mengemuka. Identitas calon pemimpin ditelusuri sedemikian intens hingga kepada persoalan agama yang dianut. Keinginan memilih pemimpin yang seagama dengan mayoritas konstituen terus digaungkan. Tidak jarang fenomena ini mengundang para ulama untuk mengeluarkan fatwa tentang larangan memilih pemimpin yang tidak seagama dengan mayoritas masyarakat. Dengan kata lain, umat Islam dilarang memilih pemimpin non Muslim yang berasal dari bangsa (sebagian menyebutnya agama) Yahudi dan Nasrani sebagaimana diisyaratkan dalam pesan QS. al-Ma'idah/5: 51. Menariknya, yang menjadi core perdebatan adalah sekitar penafsiran kata awliyâ' yang terdapat dalam ayat tersebut. Kontroversi penafsiran diawali oleh pernyataan salah seorang pejabat publik 
setingkat gubernur beberapa tahun lalu tentang pemilihan kepala daerah yang sifatnya pribadi dan tidak perlu dipengaruhi oleh siapa pun. Pernyataan yang menjadi sorotan utama adalah ketika sang pejabat mengatakan "Jadi jangan percaya sama orang. Kan bisa saja dalam hati kecil bapak ibu enggak bisa pilih saya. Karena dibohongin pakai surat Al Maidah 51 macem-macem gitu lho". ${ }^{1}$ Meskipun pada awalnya belum ada reaksi dari umat Islam secara massive terhadap pernyataan tersebut, belakangan salah seorang dosen di sebuah perguruan tinggi Jakarta mengunggahnya ke media sosial dengan tema "Penistaan terhadap Agama?" Dari sinilah berawal fenomena saling lapor, pro dan kontra mengemuka dari masingmasing pihak sehingga mendapat perhatian luas dari umat Islam yang kemudian melahirkan apa yang disebut dengan gerakan 411 dan 212.

Penulis menemukan sedikitnya ada empat versi terjemahan Al-Qur'an yang memberi arti pada kata itu secara berbeda, yaitu sesuai dengan kata aslinya, awliyấ; wali, ${ }^{2}$ pemimpin, ${ }^{3}$ teman setia, ${ }^{4}$ teman-teman (friends) dan pelindungpelindung (protectors). ${ }^{5}$ Menurut M. Quraish Shihab, kata awliyâ' sejatinya tidaklah mutlak tepat diterjemahkan dengan pemimpin, karena kata yang merupakan bentuk jamak dari wali itu pada dasarnya berarti dekat. Dengan demikian wajar belakangan muncul kata-kata yang mengandung unsur kedekatan, seperti pendukung, pembela, pelindung, yang mencintai, lebih utama dan sebagainya. Karena itu, seorang ayah dikatakan wali atas anak perempuan, orang yang sangat tekun beribadah kepada Allah disebut wali, dan seseorang disebut pemimpin lantaran sedemikian dekatnya dengan orang yang dipimpinnya. Ini mengisyaratkan bahwa kata awliy $\hat{a}$ ' meliputi makna-makna tersebut. ${ }^{6}$

${ }^{1}$ Lihat https://news.detik.com. "Kontroversi Ahok Soal Al Maidah 51" (7 Oktober 2016) diakses 5 April 2021.

2 "Hai orang-orang yang beriman, janganlah kamu mengambil orang-orang Yahudi dan Nasrani menjadi wali (mu), sebahagian mereka adalah wali bagi sebahagian yang lain ..." Lihat Departemen Agama RI, Al-Quraan dan Terjemahnya (Jakarta: Proyek Pengadaan Kitab Suci AlQur'an Departemen Agama RI, 1984), h. 169.

3 "Hai orang-orang yang beriman, janganlah kamu mengambil orang-orang Yahudi dan orang-orang Nasrani menjadi pemimpin-pemimpin (mu), sebahagian mereka adalah pemimpin bagi sebahagian yang lain ..." Lihat Departemen Agama RI, Al-Qur'an dan Terjemabnya (Semarang: CV. Toha Putra, 1989), h. 169.

4 "Wahai orang-orang yang beriman! Janganlah kamu menjadikan orang Yahudi dan Nasrani sebagai teman setia (mu), mereka satu sama lain saling melindungi ..." Lihat Departemen Agama RI, Al-Qur'an dan Terjemabnya (Jakarta: CV. Naladana, 2004), h. 155.

5 "O ye who believe! take not the Jews and the Christians for your friends and protectors; they are but friends and protectors to each other ..." Lihat 'Abdullah Yusuf 'Ali, The Holy Qur'an with English Translation \& Selected Commentaries (Kuala Lumpur: Saba Islamic Media, 2008), h. 142.

${ }^{6}$ M. Quraish Shihab, Tafsir al-Mishbah: Pesan, Kesan dan Keserasian Al-Qur'an, vol. 3 (Ciputat, Tangerang: Penerbit Lentera Hati, 2006), h. 123. 
Sementara itu, dalam sejumlah karya tafsir ditemukan pula variasi penafsiran terhadap kata awliy $\hat{a}^{\prime}$ yang tercantum pada QS. al-Ma'idah/5: 51. Abdullah bin Abbas menegaskan bahwa orang-orang yang beriman kepada Nabi Muhammad dan Al-Qur'an dilarang menjadikan kaum Yahudi dan Nasrani sebagai penolong, karena mereka itu saling membantu dalam membela agamanya, baik secara terbuka maupun tersembunyi. ${ }^{7}$ Ada pula yang berpendapat bahwa ayat ini berisi larangan kepada umat Islam untuk menjadikan orang-orang Yahudi dan Nasrani sebagai teman dekat, apalagi dipercaya sebagai pemimpin. ${ }^{8}$ Bagi Sayyid Quthb, pengertian wilayah pada ayat ini adalah saling memberikan kesetiaan kepada mereka (Yahudi dan Nasrani), dan tidak terkait sama sekali dengan makna mengikuti agama mereka. Sebagian umat Islam, terutama di Madinah, ketika itu masih menjalin hubungan dengan orang-orang Yahudi dengan alasan loyalitas, transaksi bisnis, tetangga dan persahabatan. Hal ini wajar, karena sebelum Islam datang, orang-orang Arab telah berinteraksi dengan kaum Yahudi, terutama dalam perspektif historis, perekonomian dan kemasyarakatan. ${ }^{9}$ Pendapat yang agak moderat dikemukakan oleh al-Maraghi bahwa apabila persahabatan dan pertolongan yang dilakukan antar umat yang berbeda agama hanya sebatas menciptakan kemaslahatan duniawi saja, maka tidaklah termasuk hal yang dilarang ayat ini..$^{10}$

Mencermati penerjemahan dan penafsiran di atas, terdapat sejumlah kemungkinan arti dan pemahaman kata awliy $\hat{a}$ '. Apakah secara kebetulan atau tidak hal ini seringkali dikaitkan dengan momentum pemilihan kepala daerah (pilkada), ketika masing-masing pihak bersikukuh mengemukakan pandangannya tentang kata tersebut sesuai dengan situasi dan kondisi yang mereka hadapi. Kajian ini pada akhirnya diharapkan dapat menjawab pertanyaan mengapa terjadi kontroversi penafsiran terhadap QS. al-Ma'idah/5: 51 dan bagaimana persepsi tokoh ulama dan adat Jambi mengenai pemilihan pemimpin yang berbeda keyakinan dengan mayoritas pemilihnya. Jawaban atas pertanyaan tersebut akan membuktikan sejauh mana pandangan tokoh agama dan adat di provinsi Jambi berbeda dengan yang lain atau hanya sekedar menggarisbawahi saja. Dari sini diketahui pula ada tidaknya nilai-nilai kearifan lokal yang mereka wariskan kepada generasi belakangan dalam menghadapi perkembangan dan dinamika kehidupan bermasyarakat dan berbangsa di masa mendatang.

${ }^{7}$ Abdullah bin Abbas, Tanwîr al-Miqbâs min Tafsîr Ibn 'Abbâs, ed. Muhammad bin Ya'qub al-Fairuzabadi (Beirut: Dar al-Kutub al-Ilmiyah, 2008),h. 125. 2004), h. 416.

${ }^{8}$ Departemen Agama RI, Al-Qur'an dan Tafsirnya, jilid 2 (Jakarta: Departemen Agama RI, 2010), h.252.

'Sayyid Quthb, Tafsir fi Zhilalil Qur'an, terj. As'ad Yasin, jilid 3 (Jakarta: Gema Insani,

${ }^{10} \mathrm{Ahmad}$ Musthafa al-Maraghi, Tafsîr al-Marâghî, jilid 2 (Beirut: Dar al-Fikr, 1974), h. 136137. 
Beberapa kajian telah dilakukan sekitar kepemimpinan non Muslim dan metode penafsiran yang digunakan, di antaranya ditulis oleh M. Suryadinata, ${ }^{11}$ Abu Thalib Khalik, ${ }^{12}$ Musholli Ready, ${ }^{13}$ Ahmad Syukri Saleh, ${ }^{14}$ dan Atik Wartini. ${ }^{15}$ Penelitian ini dilakukan di Provinsi Jambi, terutama yang berkaitan dengan persepsi tokoh ulama dan adat Melayu Jambi sekitar kontroversi penafsiran QS. al-Ma'idah/5: 51 serta pengangkatan pemimpin non-Muslim sebagai pejabat publik. Penelitian ini menggunakan metode kualitatif, di mana pengumpulan data dilakukan melalui observasi, wawancara dan dokumentasi. Observasi dilakukan secara langsung terhadap informan, bahasa yang digunakan dan sikap yang diperlihatkannya dalam merespon setiap pertanyaan yang diajukan. Penentuan informan penelitian dengan cara purposive sampling, yang melibatkan tokoh agama dan adat yang berkecimpung dalam organisasi keagamaan seperti Nahdlatul

${ }^{11}$ M. Suryadinata, “Kepemimpinan Non Muslim dalam al-Qur'an: Analisis terhadap Penafsiran Front Pembela Islam (FPI) mengenai Ayat Pemimpin Non Muslim”, Jurnal Ilmu Ushuluddin, Vo. 2 No. 3, Januari-Juni 2015.

$12 \mathrm{Abu}$ Thalib Khalik, Pemimpin Non-Muslim dalam Perspektif Ibnu Taimiyah,ANALISIS: Jurnal Studi Keislaman, Vol. 14, No. 1, Juni 2014.

${ }^{13}$ Musholli Ready, Arus Baru Kecenderungan Penafsiran Kontemporer, Journal of Qur'ân and Hadith Studies, Vol. I, No. I, (2011).

${ }^{14}$ Ahmad Syukri Saleh, Korelasi Ayat dan Surat dalam Perspektif Kontekstualisasi Redaksional al-Qur'an (Ciputat, Jakarta: Refleksi, 2014); An Understanding of Some Interpretations of the Qur'an by Textual and Contextual Approaches, seminar prosiding in International Cenference on Qur'an and Hadith Studies, Advances in Social Science, Education and Humanities Research (ASSEHR), Vol. 137 (2018).

${ }^{15}$ Atik Wartini, Corak Penafsiran M. Quraish Shihab dalam Tafsir al-Misbah”, Hunafa: Jurnal Studia Islamika Vol. 11, No. 1 (2014). 
Ulama, ${ }^{16}$ Muhammadiyah ${ }^{17}$ dan Front Pembela Islam ${ }^{18}$ (sebelum dibubarkan secara resmi oleh pemerintah) di Provinsi Jambi. Dipilihnya sejumlah tokoh agama dan adat yang bernaung dalam organisasi sosial keagamaan dan kemasyarakatan tersebut sebagai subjek penelitian bukan tanpa alasan. Pertama, karena peran mereka sangat potensial dalam menyuarakan aspirasi umat Islam. Kedua, mereka juga berkiprah di perguruan tinggi, pondok pesantren, madrasah dan majelis taklim serta lembaga adat. Ketiga, tokoh agama dan adat yang bernaung dalam organisasi dan lembaga resmi memudahkan peneliti dalam mengakses informasi sehingga dapat dipertanggungjawabkan. Langkah berikutnya, data yang telah dihimpun dianalisis melalui tahapan reduksi data, penyajian data dan penarikan kesimpulan/ verifikasi (flow model analysis).

\section{Pembahasan}

Pasca publikasi pernyataan pejabat publik yang dianggap menistakan agama itu, paling tidak sedikitnya muncul tiga kecenderungan penafsiran. Ada yang mengatakan bahwa pernyataan itu secara tegas merupakan penistaan agama, ada yang memandangnya bukan penistaan agama dan ada pula yang menafsirkan tanpa memihak kepada masing-masing pro dan kontra tersebut. Pihak yang secara tegas menyikapi pernyataan itu sebagai penistaan agama berasal dari Majelis Ulama Indonesia (MUI) pusat yang menyimpulkan bahwa ucapan sang pejabat mengarah kepada penghinaan Al-Qur'an dan ulama yang memiliki konsekuensi

${ }^{16}$ Organisasi keagamaan ini berdiri secara resmi pada tanggal 16 Rajab 1344 H/ 31 Januari 1926 di Surabaya dengan pimpinan pertamanya Hadratus Syeikh K. H. Hasyim Asy'ari. Tujuan pendirian organisasi ini adalah ingin menerapkan ajaran Islam dengan mempedomani aliran mainstream Ahlusunnah waljama'ah (Aswaja) yang mengakomodir salah satu dari empat mazhab Sunni terkemuka (Hanafi, Maliki, Syafi'i dan Hanbali), dalam kehidupan bermasyarakat, berbangsa dan bernegara di bawah kedaulatan Negara Kesatuan Republik Indonesia yang berdasarkan Pancasila dan Undang-Undang Dasar 1945. Secara historis, kelahiran organisasi ini sebagai "reaksi defensif terhadap perkembangan paham pembaruan dalam Islam di Tanah Air yang dikembangkan oleh Muhammadiyah, sebagai upaya mempertahankan ajaran tradisional dan mazhab di tanah suci, yang baru dikuasai oleh golongan Wahabi di bawah Raja Abdul Aziz bin Saud." Lihat Bahrul Ulum, "Bodohnya NU" apa "NU Dibodobi"? Jejak Langkah NU Era Reformasi: Menguji Khittah, Meneropong Paradigma Politik (Yogyakarta: Penerbit Ar-Ruzz Press, 2002),h. 56.

${ }^{17}$ Organisasi ini berdiri secara resmi di Yogyakarta pada tanggal 18 November 1912 yang diprakarsai oleh K. H. Ahmad Dahlan. Pendirian Muhammadiyah hampir beriringan dengan hadirnya sejumlah organisasi keagamaan lainnya seperti Jami'iyyat Khair (1905), Sarekat Dagang Islam (1909), Persyarikatan Ulama (1911) dan Sarekat Islam (1912. Lihat Suaidi Asyari, Nalar Politik NU \& Muhammadiyab: Over Crossing Java Sentris (Yogyakarta: LKiS, 2009), h. 41-42.

${ }_{18}$ Organisasi ini berdiri pada tanggal 24 Rabi al-Tsani 1419 H/ 17 Agustus 1998 yang diprakarsai oleh para Habaib, Ulama dan Muballigh serta santri se-Jabotabek dengan tujuan utamanya menerapkan syariat Islam pasca lengsernya Presiden Soeharto. Lihat Jamhari dan Jajang Jahroni, Gerakan Salafi Radikal di Indonesia (Jakarta: RajaGrafindo Persada, 2004), h. 130. 
hukum. Pernyataan sikap keagamaan MUI ${ }^{19}$ ini ditanda tangani oleh Ketua Umum, K. H. Ma'ruf Amin (saat ini Wakil Presiden RI) dan Sekretaris Jenderal, K. H. Anwar Abbas pada tanggal 5 Oktober 2016. Pernyataan sikap MUI ini kemudian dikirim ke seluruh pimpinan MUI se-Indonesia, tidak terkecuali MUI Provinsi Jambi, agar ikut merespon dan memberikan dukungan. Setelah menerima salinan pernyataan sikap MUI tersebut, Ketua dan Sekretaris MUI Jambi segera mengundang unsur pimpinan MUI lainnya untuk melakukan pertemuan dalam rangka merespon, membahas dan mendukung sikap keagamaan itu. Hasil dari pertemuan tersebut menegaskan bahwa MUI Provinsi Jambi mendukung penuh atas sikap keagamaan yang telah diputuskan oleh MUI pusat. Surat dukungan ini kemudian dikirim ke Pengurus MUI pusat dan ditembuskan ke beberapa lembaga pemerintahan. ${ }^{20}$ Sikap tegas MUI pusat ini didukung kuat oleh ormas-ormas Islam di Indonesia dan beberapa tokoh ulama terkemuka, di antaranya Yunahar Ilyas, salah satu Ketua Pengurus Pusat Muhammadiyah, yang menyatakan bahwa 'Ucapan Ahok yang berbunyi 'dibohongi pakai Al-Maidah ayat 51,' mengandung unsur penistaan terhadap ulama dan Surat Al-Maidah Ayat 51". ${ }^{21}$

Sementara itu, tidak sedikit juga tokoh agama yang menyesalkan keluarnya sikap keagamaan MUI tersebut, di antaranya Buya Ahmad Syafii Maarif, ${ }^{22}$ mantan Ketua Umum Pengurus Pusat Muhammadiyah dan Hamka Haq, ${ }^{23}$ anggota DPR RI dari Partai Demokrasi Indonesia Perjuangan. Keduanya mengkritisi sikap keagamaan MUI yang tidak cermat menilai ucapan Ahok dan terkesan ada tekanan

\footnotetext{
${ }^{19}$ Berikut ini beberapa bagian penting dari pernyataan sikap keagamaan MUI pusat bahwa "Sehubungan dengan pernyataan Gubernur Provinsi DKI Jakarta Basuki Tjahaja Purnama di Kabupaten Kepulauan Seribu pada hari Selasa, 27 September 2016, setelah melakukan pengkajian, menyampaikan sikap keagamaan sebagai berikut: 1. Al-Qur'an surah al-Maidah ahyat 51 secara eksplisit berisi larangan menjadikan Yahudi dan Nasrani sebagai pemimpin. Ayat ini menjadi salah satu dalil larangan menjadikan non Muslim sebagai pemimpin. 2. Ulama wajib menyampaikan isi surah al-Maidah ayat 51 kepada umat Islam bahwa memilih pemimpin muslim adalah wajib. 3 . Setiap orang Islam wajib meyakini kebenaran isi surah al-Maidah ayat 51 sebagai panduan dalam memilih pemimpin. 4. Menyatakan bahwa kandungan surah al-Maidah ayat 51 yang berisi larangan menjadikan Yahudi dan Nasrani sebagai pemimpin adalah sebuah kebohongan, hukumnyaharam dan termasuk penodaan terhadap al-Qur'an, dan 5. Menyatakan bohong terhadap ulama yang menyampaikan dalil surah al-Maidah ayat 51 tentang larangan menjadikan nonmuslim sebagai pemimpin adalah penghinaan terhadap ulama dan umat Islam.'Lihat https://news.detik.com. "MUI Nyatakan Sikap Soal Ucapan Ahok Terkait Al Maidah 51, ini Isinya" (11 Oktober 2016) diakses 5 April 2021.

${ }^{20}$ Wawancara dengan Sekretaris Umum MUI Provinsi Jambi, 2 Agustus 2017.

${ }^{21}$ Lihat https://tirto.id. "Ulama Muhammadiyah Anggap Ahok Sengaja Menodai Agama" (21 Februari 2017) diakses 10 April 2021.

${ }^{22}$ Komentar Buya Ahmad Syafii Maarif dapat dilihat pada https://beritasatu.com. "Buya Syafii: Ahok Tidak Menghina Alquran” (7 November 2016) diakses 15 April 2021.

${ }^{23}$ Penilaian Hamka Haq ini dapat dilihat pada https://viva.co.id.berita.metro "Saksi Ahli Agama Pihak Ahok Curiga Niat MUI Keluarkan Fatwa” (29 Maret 2017) diakses 20 April 2021.
} 
dari kelompok tertentu untuk mengeluarkan sikap keagamaan. Mereka menganggap sikap tersebut tidak netral. Namun, di sisi lain, sikap yang dikeluarkan MUI itu dinilai oleh berbagai pihak sebagai respons yang cerdas dan cepat karena suasana politik pada waktu itu sedang "hangat" pasca pernyataan Ahok yang dianggap menistakan Al-Qur'an sehingga memancing emosi sebagian umat dan ormas Islam yang dikhawatirkan akan menimbulkan gejolak yang tidak terkontrol. Jadi, sikap MUI ini menjadi oase yang efektif untuk meredakan suasana yang sempat memanas. MUI pun ketika itu lebih memilih sebuah diksi dalam bentuk pernyataan sikap keagamaan ketimbang fatwa, karena fatwa sifatnya lebih mengikat bagi umat Islam.

Pandangan yang dianggap bernada netral dikemukakan oleh Sahiron Syamsuddin, akademisi UIN Sunan Kalijaga Yogyakarta, dengan menghindari pro kontra yang terjadi menyangkut pernyataan Ahok, yang memandang sisi linguistik surat al-Ma'idah ayat 51 tersebut. Sahiron lebih memfokuskan pada analisis kebahasaan menyangkut kata awliy $\hat{a}$ ' dan konteks penggunaannya pada masa Nabi Muhammad Saw serta penafsiran ulama menyangkut kata tersebut. Kata awliy $\hat{a}^{\prime}$ tidak hanya dipahami sebagai teman dekat atau pemimpin, tetapi ada pesan dalam pernyataan Ahok itu selain menyinggung ayat yang terkait dengan kepemimpinan, tetapi juga menyentil pihak-pihak yang selama ini memanfaatkan ayat tersebut untuk menjegal lawan politik dalam pemilihan pemimpin sebagai kepala daerah. ${ }^{24}$

Berdasarkan analisis faktual di atas, terdapat tiga trend penafsiran. Pertama, pernyataan tersebut secara tekstual sudah termasuk menista agama. Kedua, pernyataan tersebut belum termasuk penistaan agama karena ada faktor lain yang bisa dipahami, terutama secara kontekstual. Ketiga, pernyataan itu harus dipahami secara tekstual dan kontekstual. Karena memahami teks tanpa konteks sama kelirunya dengan memahami konteks tanpa teks. Pemahaman secara tekstual ansich akan melahirkan kekakuan (rigidity), kedangkalan dan kepicikan. Sebaliknya, pemahaman secara kontekstual saja akan menimbulkan kesan terlalu cair, membingungkan dan tidak konklusif. Sebagai ilustrasi, Al-Qur'an sebagai teks suci tidak pernah hadir di ruang kosong, sehingga ia dapat semena-mena muncul dan mengisi yang ada. Ia senantiasa bertempat dan menetap di ruang yang di dalamnya manusia dan alam sudah saling berinteraksi dan saling memanfaatkan. Perbedaan perspektif dan kecenderungan subjektif penafsir terhadap objek tafsir sangatlah mempengaruhi pemikiran dan sikap yang dilakukannya, dan itulah faktor yang menimbulkan perbedaan dalam menafsirkan sebuah objek, terutama QS. alMa'idah/5: 51.

${ }^{24}$ Komentar Sahiron Syamsuddin dapat dilihat pada https://news.detik.com.berita "Sidang Ahok, Ahli Agama Paparkan Pemahaman Al Maidah 51" (29 Maret 2017) diakses 24 April 2021. 
Kontroversi sekitar penafsiran kata awliyâ' dalam QS. al-Ma'idah/5: 51 tidak saja terbatas direspons oleh tokoh ulama pada level nasional, tetapi juga ditanggapi oleh tokoh agama dan tokoh adat di daerah, khususnya Provinsi Jambi. Sejumlah persepsi bermunculan dari berbagai ormas Islam (Nahdlatul Ulama, Muhammadiyah, Front Pembela Islam dan Majelis Ulama Indonesia) yang diekspresikan dalam bentuk pernyataan sikap, surat terbuka, melapor kepada pihak terkait, menulis di media masa dan melakukan orasi unjuk rasa (demonstrasi). Menurut H. Abdul Kadir Husein, salah satu tokoh Nahdlatul Ulama dan wakil ketua MUI bahwa:

Kasus penistaan agama oleh Abok ini selain mendiskreditkan agama kita, di sisi lain telah membuat umat Islam, terutama ormas Islam bangkit bersatu menghadapi penistaan agama itu, dan berupaya memahami lebih mendalam tentang kandungan isi Al-Qur'an surat al-Ma'idah 51 yang begitu dalam dan luas cakupannya. Kasus ini ada bikmahnya, setidaknya mengingatkan kita untuk selalu membaca dan mengkaji Al-Qur'an. Kalau kita kurang mengkaji, berarti kita mengabaikan atau kurang menghormatinya. Kalau kita saja kurang menghormati, bagaimana mungkin orang lain mau menghormati? Karena kita dalam sebuah negara mayoritas Islam seperti ini, maka kita mesti memilih pemimpin dari umat Islam, jika dalam kondisi darurat karena kita berada di zona-zona yang non muslim, maka kita harus menyesuaikan diri demi keselamatan umat. ${ }^{25}$

Hasbullah Ahmad, Ketua Lembaga Dakwah NU Provinsi Jambi, ketika dimintai pandangannya menyangkut QS. al-Ma'idah/5: 51 menyatakan bahwa:

Apa yang diucapkan Abok di Pulau Seribu itu selain tidak tepat karena menafsirkan Al-Qur'an yang bukan ranabnya. Itu ranah umat Islam, terutama para ulamanya. Ucapannya juga telah menyinggung perasaan umat beragama, terutama umat Islam yang mayoritas di Indonesia. Munculnya perdebatan soal berbagai penafsiran terbadap QS. al-Ma'idab/5:51 tersebut terjadi karena perbedaan perspektif, ada yang melihat konteks tafsir ini melalui asbâb al-nuzûl dengan menyatakan bahwa kasus turunnya ayat ini bukan pada larangan memilih pemimpin non muslim, akan tetapi larangan menjadikan mereka (orang kafir) sebagai teman setia yang sewaktu-waktu dapat menghancurkan kita. Perbedaan terjadi pada kata awliyấ, ada yang menerjemabkannya dengan pemimpin dan ada pula dengan teman setia. Kepemimpinan adalah salah satu aspek yang sangat penting dan strategis dalam Islam. Membicarakan siapa pemimpin adalah sangat penting, karena orang yang memiliki otoritas sebagai pemimpin akan mudah mempengarubi kepentingan umat dan kehidupan beragama

25Wawancara tanggal 2 September 2017. 
serta bernegara dalam suatu negeri. Bila umat Islam tidak peduli politik, maka akan dipimpin oleh politikus yang tidak mempedulikan umat Islam. ${ }^{26}$

Senada dengan pandangan di atas, Ahmad Syukri, SS. Ketua bidang Tarjih Pimpinan Wilayah Muhammadiyah Provinsi Jambi mengatakan bahwa:

QS. al-Maidah ayat 51 adalah salab satu dari belasan ayat yang berhubungan dengan larangan mengangkat pimpinan dari kalangan non muslim. Oleh karena itu, penafsirannya harus dipadukan satu sama lain. Selain itu, penafsiran ayat ini tidak bisa hanya sepotong ayat. Sebab, potongan ayat selanjutnya (sebahagian mereka adalah pemimpin bagi sebahagian yang lain) adalah alasan atau dasar adanya larangan tersebut. Kata walî atau awliyâ' (jamak) memiliki banyak makna, antara lain teman, kawan setia, penolong, sekutu, pelindung, pemimpin, kekasib, dan lainnya. Pada ayat ini, semua makna tersebut bisa berlaku, sebab substansinya adalab babwa orang beriman dilarang masuk dalam lingkungan pengarub dan kekuasaan mereka. ${ }^{27}$

Pandangan yang tidak kalah menarik selanjutnya dikemukakan oleh Habib Taufik, Ketua Front Pembela Islam Provinsi Jambi bahwa:

Kata awliyâ' pada surat al-Ma'idah ayat 51 bermakna "wali" yang dalam bahasa Indonesia memiliki beragam makna. Ada makna teman dekat, orang kepercayaan, pelindung, penolong atau pemimpin. Meskipun berbeda makna, semua ulama sepakat ayat tersebut menjadi acuan umat muslim agar tidak memilib pemimpin dari non muslim. Jadi teman dekat saja tidak boleh, apalagi jadi pemimpin. Ketika kita berhadapan dengan dua pilihan yang sama-sama memiliki mudharat, maka piliblah mudharat yang lebih kecil, seperti kaidah mengatakan: "Mengambil mudharat yang paling ringan" atau kaidah "Apabila ada dua mafsadat yang bertemu (yang harus dikerjakan salah satunya), maka yang dibindari adalah mudharat yang lebih besar dengan melakukan mudharat yang lebih ringan". Hal ini dapat berlaku apabila kita tinggal di wilayah yang penduduknya mayoritas non muslim dan harus memilih pemimpin yang pilibannya semuanya non muslim, maka piliblab di antara calon pemimpin itu yang lebih kecil resistensinya pada umat Islam, atau piliblah yang dianggap lebih mampu berlaku adil dan tidak mendiskreditkean umat Islam. ${ }^{28}$

Dari beberapa pandangan di atas dapat dipahami bahwa meskipun kata awliyâ' dalam QS. al-Ma'idah/5: 51 mempunyai makna yang beragam, umat Islam tetap diharuskan memilih pemimpin yang seagama. Karena dalam Islam, persoalan kepemimpinan merupakan sesuatu yang sangat strategis dan berkaitan erat dengan jaminan ketentraman dan keadilan dalam kehidupan masyarakat secara luas. Ini tidak berarti bahwa non muslim tidak bisa menjadi pemimpin bagi mayoritas muslim. Karena sejauh ia mampu menghadirkan kesejahteraan dan

\footnotetext{
${ }^{26}$ Wawancara tanggal 4 September 2017.

${ }^{27}$ Wawancara tanggal 7 September 2017.

${ }^{28}$ Wawancara tanggal 6 September 2017.
} 
keadilan bagi masyarakat bisa saja dipilih sebagai pemimpin. Tetapi pada faktanya hal itu tidak mudah untuk direalisasikan. Oleh karena itu, demi menghindari resistensi dan terciptanya stabilitas masyarakat dalam semua lini kehidupan, ada baiknya pemimpin dipilih dari pemeluk agama mayoritas. Sementara itu, selaku pejabat publik harus berhati-hati dalam menyampaikan pesan kepada masyarakat dan menghindari pendiskreditan terhadap agama tertentu. Kemudian jika ingin memberikan penilaian terhadap keyakinan dan pemahaman agama harus berdasarkan pengetahuan yang mumpuni, tidak asal memberikan komentar yang menimbulkan keresahan di masyarakat. Apalagi jika materi yang ingin disampaikan itu mengundang penafsiran yang berbeda-beda dan harus dipahami sesuai dengan konteksnya. Seorang pejabat publik juga mesti mengkaji secara cermat implikasi dari pernyataan yang akan diutarakan di hadapan masyarakat sehingga tidak menimbulkan penolakan yang mengarah kepada hilangnya kepercayaan mereka terhadap pemimpinnya. Dengan kata lain, pejabat publik harus pandai membaca psikologi masyarakat dan jangan mengumbar pernyataan yang bernuansa sensitif, bahkan provokatif yang akan mengakibatkan perasaan masyarakat terluka. Alih-alih ingin mendapatkan simpati dan dukungan publik, malah membuat mereka semakin menjauh dan kehilangan harapan. Hal ini senada dengan pepatah hukum adat, tidak terkecuali Adat Melayu Jambi, bahwa "pikir dulu baru bakato, jangan dikatokan apo yang dipikirkan, Lihat dulu baru melangkah, jangan melangkah baru melihat". ${ }^{29}$ Maksudnya, setiap pernyataan yang akan disampaikan harus dipertimbangkan secara matang, baik dan buruknya, begitu juga setiap upaya yang akan dijalankan sudah direncanakan jauh-jauh hari. Berapa banyak peristiwa yang tidak menguntungkan bersumber dari kelalaian dalam mengantisipasi akibat yang akan dipikul nantinya.

Berkaitan dengan persepsi tokoh adat Melayu, ketika ditanyakan secara lebih spesifik apakah ada dalam adat Melayu Jambi ketentuan yang mengatur bahwa pengangkatan atau penunjukkan pemimpin diharuskan dari kalangan umat Islam, Azra'i al-Basyari, selaku Ketua Lembaga Adat Melayu Kota Jambi dan Sekretaris Lembaga Adat Rumpun Melayu se-Sumatera, memberikan jawaban bahwa "karena adat Jambi mengacu kepada prinsip "Adat bersendi syara' dan syara' bersendi Kitabullah" dalam pengertian "Syara" mengato dan adat memakai", maka dengan demikian yang menjadi pemimpin mutlak beragama Islam". ${ }^{30}$ Pendapat ini juga didukung oleh tokoh adat Datuk Muchtar Agus Cholif, selaku Wakil Ketua Lembaga Adat Melayu (LAM) Jambi, yang mensinyalir bahwa:

\footnotetext{
${ }^{29}$ Muchtar Agus Cholif, Sumpit Gading Damak Ipub Hukum Adat Melayu Jambi (Jambi: Salim Media Indonesia, 2019), h. 94.

${ }^{30}$ Wawancara tanggal 8 September 2017. Hal senada juga didukung oleh Hasan Basri Jamik, salah satu tokoh adat Melayu Jambi. Wawancara tanggal 9 September 2017. Penulis telah
} 
Pemimpin orang Jambi semuanya harus beragama Islam. Tidak boleh tidak beragama Islam. Orang Jambi menurut adat harus tunduk dengan prinsip "Adat bersendi syara', syara' bersendi kitabullab". Anak lahir harus diazankan secara Islam, jika mati harus diselenggarakan secara Islam, kalau kawin juga secara Islam. Melayu adalah Islam, Islam adalah Melayu. Ini tidak bisa ditawar lagi. Sejaub ini tidak ada tokoh adatyang berasal dari non-Muslim. ${ }^{31}$

M. Saman Sulaiman, salah seorang akademisi dan pengamat adat Melayu Jambi menegaskan bahwa:

Jika kembali kepada adat, pemimpin harus Muslim, baligh dan berakal dan sudah berumah tangga dan rumah tangganya berjalan normal. Artinya orang yang masih lajang atau rumah tangganya berantakan tidak boleh jadi pemimipin. Non Muslim menurut Adat Jambi tidak boleh memimpin rakyat Jambi. Tidak berlaku minoritas memimpin mayoritas. Rumah tangga adalah miniatur wilayah. Jika memimpin rumah tangga tidak beres, bagaimana memimpin masyarakat. Dalam hal ini, masyarakatlah yang menjadi tolak ukur. ${ }^{32}$

Fathuddin Abdi, salah satu tokoh adat Kabupaten Batanghari, ketika ditanyakan tentang pemimpin menurut adat Melayu Jambi menyatakan bahwa:

Perilaku dan sikap pemimpin harus bisa mengayomi masyarakat. Harus jujur, adil, arif dan bijaksana sesuai dengan syariat. Karena " Adat bersendi syara', syara' bersendi kitabullab". Orang Melayu sudah jelas agamanya Islam. Tidak boleh pemimpin berasal dari non Muslim, kecuali masuk sebagai pengurus adat dari suku semendo, sebagai perwakilan komunitas adat. Cuma ada pemahaman yang keliru ketika memahami ungkapan "Adat bersendi syara', syara' bersendi kitabullab" menerjemabkan kitabullah termasuk. Taurat, Zabur dan Injil. Kalau kini kitabnya tidak seperti yang asli yang disebut dengan abli kitab. Kalau kitab yang asli itu masih bisa ditolerir. ${ }^{33}$

Pengangkatan pemimpin dalam tradisi adat Melayu yang mesti beragama Islam sejalan dengan masyarakat yang dipimpinnya. Karena orang Melayu, termasuk di Jambi, tidak bisa dipisahkan dari Islam. Dengan kata lain, Islam adalah Melayu dan Melayu adalah Islam. Hal ini diisyaratkan dari rumusan kalimat "Alif ado" merujuk kepada keberadaan Allah Yang Maha Esa, tiada tuhan yang disembah selain Allah, dan kalimat "Mim terjadi" bahwa Nabi Muhammad sebagai Rasul Allah sebagai panutan utama. ${ }^{34}$

mengkonfirmasi dengan beberapa tokoh Adat Jambi bahwa selama ini tidak ditemukan tokoh adat Melayu Jambi yang berasal dari non-Muslim. Wawancara tanggal 21 Agustus 2021 dan 30 Agustus 2021.

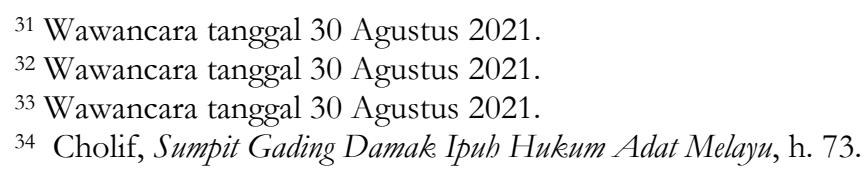


Selain persyaratan pemimpin itu mestilah beragama Islam, Fachruddin Saudagar, salah satu tokoh adat Melayu Jambi, dalam artikelnya "Pemimpin dalam Adat" menyatakan bahwa seorang pemimpin haruslah mencerminkan perilaku yang terpuji meliputi: "jujur, adil, cerdik (cerdik idak membuang kawan, gemuk idak membuang lemak, tukang idak membuang kayu, gedang idak melando, panjang idak melilit), pandai (meletakkan sesuatu pada tempatnya), menjunjung kebenaran (bekato benar bejalen lurus, memakai suci memakan halal), arif bijaksana (bekato dulu sepatah, netak mutus, makan habis) dan menjadi tempat betanyo (pergi tempat betanyo, balik tempat beberito)." ${ }^{35}$ Perilaku terpuji yang terakhir ini mengisyaratkan bahwa seorang pemimpin merupakan tokoh panutan dan sekaligus menjadi sumber pengetahuan bagi masyarakatnya. Disebutkan dalam Taj al-Salatin (Mabkota Para Sultan), seperti dikutip Mashudi Antoro, bahwa seorang pemimpin (raja, presiden, gubernur, dan bupati/walikota) menurut adat Melayu seharusnya memiliki 10 karakter yaitu: (1) mampu mengetahui yang baik dan yang buruk; (2) mempunyai ilmu yang mumpuni; (3) cakap dalam menunjuk pembantunya; (4) berparas tampan dan berkarakter mulia sehingga dihormati masyarakat; (5) penyantun (suka memberi dan menolong orang); (6) tidak melupakan jasa orang yang dihormati dan pandai membalas kebaikan orang; (7) tidak penakut; (8) makan dan tidur yang memadai; (9) tidak royal (10) pria (wanita bisa memimpin jika tidak punya keturunan laki-laki). Di antara karakter seorang pemimpin adalah harus memiliki pengetahuan yang tinggi dan akhlak mulia. Seorang pemimpin yang berilmu akan menyampaikan sesuatu yang benar dan bermanfaat. Dia tidak akan berbicara yang bukan bidang keahliannya. Jika ia berbicara, maka disampaikan dengan cara yang santun, tidak emosional dan tidak menyinggung perasaan atau keyakinan orang lain. Adat Melayu juga mengisyaratkan bahwa seorang pemimpin harus arif dan bijaksana. Kedua kata ini memiliki konotasi arti yang berbeda. Sifat arif mengarah kepada kemampuan seorang pemimpin dalam proses pembauran dengan masyarakat sementara bijaksana merujuk kepada potensi untuk menata ilmu yang dimilikinya sebaik mungkin. Dengan kearifan seseorang dapat meningkatkan trust orang-orang yang dipimpinnya sehingga layak disebut pemimpin. Sementara dengan kebijaksanaan mampu memandu seseorang dalam mengambil keputusan yang tepat. Keputusan ${ }_{36}$ yang diambil sudah sesuai dengan pengetahuan dan pengalaman yang dimilikinya.

Berdasarkan wawancara dan analisis di atas dapat diketahui bahwa akar perbedaan penafsiran QS. al-Ma’idah/5: 51 berkisar pada kata awliy $\hat{a}^{\prime}$. Kata yang

\footnotetext{
${ }^{35}$ Lihat https://melangun.wordpress.com, "Pemimpin dalam Adat" (19 Maret 2013) diakses 30 April 2021.

36 Lihat https://riauone.com, "Kepemimpinan Ideal dalam Tradisi Melayu" (26 September 2017) diakses 28 Agustus 2021.
} 
menjadi bentuk jamak dari kata walî ini mengandung multi arti. Di antaranya, teman, pelindung, pemimpin, penolong, sekutu, dan kekasih. Pada ayat ini semua arti tersebut bisa berlaku, sebab substansinya adalah bahwa orang yang beriman dilarang masuk dalam lingkungan pengaruh atau kekuasaan mereka. Pandangan mereka pada umumnya terdapat kesamaan ketika umat Islam berada di sebuah masyarakat, negara atau wilayah yang umatnya mayoritas non muslim. Mereka menggolongkan kondisi seperti itu sebagai kondisi darurat yang membolehkan memilih pemimpin dari kalangan non muslim jika semua calon pemimpinnya berasal dari non muslim. Dengan demikian, jika di antara calon pemimpin itu ada dari kalangan umat Islam, maka memilih yang beragama Islam lebih diprioritaskan. Akan tetapi, jika calon pemimpin itu semuanya adalah non muslim, maka pilihlah calon yang memiliki potensi paling adil dan tidak diskriminatif pada kelompok agama atau etnis lain. Namun, jika dihadapkan secara spesifik pada adat yang berlaku di Provinsi Jambi, dengan menggunakan makna dari kata awliy $\hat{a}^{\prime}$ dalam konteks memimpin sebuah wilayah atau daerah, maka keharusan pengangkatan pemimpin dari kalangan umat Islam merupakan sesuatu yang tidak bisa ditawar lagi. Selain itu, seorang pemimpin harus memenuhi sejumlah kriteria perilaku terpuji, seperti jujur, adil, cerdik, pandai, arif dan bijaksana. Pemimpin yang arif dan bijaksana lahir dari pribadi yang cerdik dan pandai menempatkan sesuatu secara proporsional. Dengan modal kecerdikan dan kepandaian inilah seorang pemimpin mampu melahirkan sebuah tindakan dan keputusan yang tepat. Keputusan yang diambil dengan penuh pertimbangan, kearifan dan kebijaksanaan.

Setelah mencermati berbagai persepsi dari para tokoh agama dan adat Melayu Jambi, ditemukan indikasi kecenderungan yang seirama dan dapat dikategorikan ke dalam pemahaman pesan Al-Qur'an secara tekstual. Pemahaman ini tidak bisa dianggap keliru, karena isyarat ayat secara tegas memang menunjukkan pada makna tersebut bahwa ada larangan bagi umat Islam untuk mengangkat pemimpin dari kalangan non muslim. Kontroversi penafsiran yang dihasilkan melalui salah satu pendekatan baik tekstual ataupun kontekstual sudah berumur panjang dan mengakar dalam sejarah Islam. Kontroversi ini berawal dari kesesatan berpikir sebagian orang bahwa masing-masing pendekatan bisa mengalahkan yang lain. Teks bisa menundukkan konteks atau sebaliknya. Padahal, keduanya harus selalu berhubungan, saling memperkuat dan mengisi, bukan saling mengalahkan dan menegasikan.

Semasa hidup Nabi Muhammad pun pernah terjadi perbedaan pemahaman dalam memaknai perintah beliau. Salah satunya dalam kasus perintah Nabi kepada para sahabat agar melaksanakan shalat Ashar di perkampungan Bani Quraizhah. Ketika perang Khandaq telah berakhir, Nabi mengumpulkan para sahabatnya. Beliau mengatakan: "Siapa yang taat dan patuh, maka janganlah dia shalat Ashar kecuali di perkampungan Bani Quraizhah!” Para sahabat ketika itu dengan mudah memahami perintah Nabi, karena dinyatakan dengan bahasa yang 
jelas dan tegas. Shalat Ashar hanya boleh dilakukan di perkampungan Bani Quraizhah. Kemudian mereka pun berangkat menuju perkampungan Yahudi itu. Akan tetapi, di tengah perjalanan sebagian dari mereka belum tiba di perkampungan yang dituju, sementara waktu Ashar hampir berakhir dan Maghrib pun segera datang. Lalu, di antara sahabat ada yang memahami perintah Nabi itu secara kontekstual yaitu "perintah untuk segera berangkat". Sewaktu kejadian ini disampaikan kepada Nabi, beliau mengambil sikap netral. ${ }^{37}$ Ada sahabat yang shalat di tengah perjalanan dan ada pula yang melanjutkan perjalanan hingga sampai di perkampungan Bani Quraizhah, sesuai dengan pendekatan dan pemahaman masing-masing. Berdasarkan peristiwa ini, ditemukan suatu teori yang membenarkan penerapan pendekatan tekstual dan kontekstual dalam memahami ajaran Islam. Buktinya, apa yang dipraktikkan para sahabat tidak mendapat teguran dari Nabi.

Oleh karena itu, para ulama menyebutkan bahwa yang paling utama dari semua hal adalah menjaga kemaslahatan manusia. Mereka mengatakan bahwa asas hukum Islam adalah menolak bahaya dan mudharat bagi manusia secara keseluruhan. Dengan demikian, teks atau konteks apa pun yang dapat dipahami sebagai mengandung bahaya atau mudharat bagi sebagian besar umat manusia, maka wajib disingkirkan atau ditundukkan demi teks dan konteks yang mampu memberi manfaat dan maslahat yang sebesar-besarnya bagi sebanyak mungkin manusia.

Tugas terbesar para ulama yang memiliki otoritas dan kompetensi untuk menafsirkan Al-Qur'an adalah agar mereka lebih mendalami kandungan AlQur'an secara tekstual dan kontekstual serta memberdayakan pendekatan pendukung lainnya seperti hermeneutika. Karena ada sementara masyarakat yang di satu sisi tidak bisa menerima keanekaragaman penafsiran, namun pada sisi lain ada yang memaksakan diri untuk menafsirkan dengan pandangan yang sepenuhnya bias dari tujuan-tujuan syariat (agama). Sudah saatnya, barangkali, untuk menumbuhkan sebuah sikap yang menghormati perbedaan pendapat dalam bentuk apapun juga, karena upaya menghapuskan perbedaan pandangan yang terjadi di tengah-tengah masyarakat merupakan sesuatu yang teramat sulit, jika tidak bisa dikatakan absurd. Selain itu, apapun bentuk perbedaan yang mengemuka dalam pergaulan di masyarakat, tidak terkecuali dalam memahami pesan agama yang termaktub dalam kitab suci, seharusnya tidak menjadi faktor yang dapat memperkeruh suasana kehidupan yang sudah sedemikian kondusif dan harmonis.

${ }^{37}$ M. Quraish Shihab, Membaca Sirab Nabi Muhammad Saw. dalam Sorotan Al-Qur'an dan Hadits-Hadits Shabih (Ciputat, Tangerang: Lentera Hati, 2014), h. 766. 
Terjadinya perbedaan pemahaman dalam menangkap pesan Al-Qur'an biasanya dipicu oleh perbedaan pendekatan dan metode tafsir. Seseorang yang menafsirkan Al-Qur'an dengan pendekatan tekstual akan berbeda dengan yang melakukan penafsiran secara kontekstual. Keduanya bisa saling membenarkan atau menafikan satu sama lainnya. Bila seseorang terpaku pada satu makna yang ditangkap dari pesan ayat, maka akan sulit untuk bertransformasi kepada makna yang lain. Sementara itu, bagi yang tidak terikat dengan satu makna yang diperoleh dari pesan Al-Qur'an, ia akan memiliki keleluasaan untuk menentukan makna mana dari sekian banyak makna yang tersedia dan dipandang lebih tepat. Adalah keliru untuk mengatakan bahwa salah satu dari kedua pendekatan tersebut mampu mengungguli yang lain. Dengan kata lain, seseorang tidak bisa mengatakan bahwa penafsiran secara tekstual bisa mengalahkan penafsiran yang dihasilkan melalui pendekatan kontekstual dan demikian pula sebaliknya. Sejatinya, kedua pendekatan itu harus dipertemukan untuk saling menopang dan mengisi, bukan saling mengungguli dan menafikan. Meskipun pada akhirnya harus ada pilihan penafsiran mana yang tepat dan sesuai dengan konteks lokalitas sebuah masyarakat atau negara. Karena, bagaimanapun juga, masyarakat memiliki pandangan-pandangan yang sudah mengakar di sepanjang hidupnya, baik yang bersumber pada ajaran agama yang diyakininya maupun dari tradisi (sejarah) yang diwariskan para pendahulunya. Oleh karena itu, tidak lah keliru jika seorang pemimpin diangkat atau ditunjuk berdasakan kehendak aspirasi masyarakat dan bangsanya. Penunjukkan pemimpin yang tidak didukung oleh mayoritas masyarakat dan bangsanya baik melalui musyawarah maupun sistem politik (demokrasi) yang disepakati hanya akan melahirkan kegaduhan dan ketidakharmonisan bagi keberlangsungan masyarakat dan bangsa itu di masa-masa mendatang.

\section{Kesimpulan}

Latar belakang terjadinya kontroversi penafsiran terhadap pesan QS. alMa'idah/5: 51 dikarenakan perbedaan pandangan dalam memahami kata awliyấ. Bervariasinya makna yang ditunjukkan oleh kata awliyâ' mengantarkan pada pemilihan makna yang bisa diselaraskan dengan konteks waktu terjadinya sebuah peristiwa. Pemilihan makna mana yang benar dan tepat sulit untuk dilepaskan dari subjektifitas penafsir, karena merasa memiliki dasar pijakan masing-masing. Kontroversi penafsiran ini tidak akan sebegitu fenomenalnya apabila masih dalam tataran teoretis, tetapi ketika dibawa kepada tataran praksis perbedaan produk penafsiran semakin menunjukkan jurang yang dalam karena melibatkan berbagai kepentingan yang ada di belakangnya. Ketika dibawa ke ranah politik praktis, maka pro dan kontra produk penafsiran tidak dapat dihindarkan. Oleh karena itu, diperlukan kearifan dalam memahami perbedaan sebuah produk karya penafsiran. Pemahaman terhadap perbedaan produk penafsiran tersebut paling tidak dapat meredam berbagai upaya yang mengarah pada pembelahan masyarakat sehingga 
dapat mengancam keutuhan dan keharmonisan hidup berbangsa dan bernegara. Perbedaan perspektif dan kecenderungan subjektif penafsir terhadap objek tafsir sangat mempengaruhi pemikiran dan sikap yang akan dilakukan, dan itulah faktor yang memicu terjadinya variasi penafsiran sebuah teks kitab suci, terutama QS. alMa'idah/5: 51.

Persepsi tokoh ulama dan adat Jambi sekitar kontroversi penafsiran QS. al-Ma'idah/5: 51 terbukti menunjukkan adanya kecenderungan pandangan dan pemahaman secara tekstual yang mengarah kepada larangan memilih pemimpin dari kalangan non muslim. Sikap ini sejatinya sejalan dengan ketentuan yang berlaku dalam adat Jambi yang mengharuskan mengangkat pemimpin dari kalangan umat Islam. Karena, walau bagaimanapun, keberadaan adat Jambi tidak terlepas dari prinsip utama yang dianut secara turun-temurun bahwa "adar bersendi syara' dan syara' bersendi Kitabullah". Dengan demikian, adat yang berlaku di wilayah Provinsi Jambi tidak bisa dipisahkan dengan ajaran Islam, bahkan merupakan sesuatu yang inherent. Selain itu, adat Jambi juga mengatur sejumlah rambu-rambu unggulan yang perlu dimiliki oleh seorang pemimpin dari level yang terendah hingga tertinggi, baik secara fisik maupun mental spiritual di tengah-tengah masyarakatnya. Sejumlah karakter utama yang harus melekat pada seorang pemimpin seakan tidak bisa ditawar lagi. Last but not least, karakter jujur, adil, cerdik, pandai, arif dan bijaksana merupakan prasyarat yang harus dimiliki siapa pun yang menjadi pemimpin di tanah Melayu ini.

\section{Saran}

Salah satu pekerjaan rumah terbesar bagi ulama yang memiliki otoritas untuk menafsirkan Al-Qur'an adalah mendalami kandungan Al-Qur'an secara tekstual dan kontekstual. Perpaduan kedua pendekatan ini dibutuhkan karena di luar sana baik disadari ataupun tidak masih banyak masyarakat yang di satu sisi tidak bisa menerima keanekaragaman penafsiran, sementara di sisi lain ada sekelompok orang yang memaksakan diri untuk menafsirkan Al-Qur'an dengan pemahaman yang sepenuhnya bias dari tujuan-tujuan agama. Oleh karena itu, perlu ditumbuhkan sebuah sikap yang menghargai perbedaan dalam bentuk apapun sehingga adanya perbedaan tersebut menjadi suatu keharusan hidup bermasyarakat yang tidak bisa dihindarkan. Selain itu, apapun bentuk perbedaan yang mengemuka diharapkan tidak menjadi faktor yang bisa mengeruhkan suasana kehidupan yang sudah sedemikian kondusif dan harmonis di tengahtengah masyarakat, bangsa dan negara.

Adanya anggapan bahwa pemahaman pesan Al-Qur'an secara tekstual lebih baik daripada kontekstual atau sebaliknya harus ditinggalkan. Sebagai gantinya, kedua pendekatan itu harus selalu terkoneksi, saling mendukung dan memperkuat, bukan saling memperlihatkan dominasi dn hegemoni satu sama 
lainnya. Kendati demikian, jika pada akhirnya ada penentuan pilihan produk penafsiran yang tepat dan relevan dengan kondisi lokalitas sebuah masyarakat, bangsa atau negara, itu pun tidak bisa dipungkiri. Hal ini dikarenakan masyarakat atau warganegara memiliki cara pandang dan pemahaman yang sudah terpatri kuat dalam hidupnya baik dengan merujuk pada ajaran agama yang dianutnya maupun dari pengalaman historis yang ditularkan para pendahulunya.Dengan demikian, hemat penulis, adalah tepat apabila seorang pemimpin dipilih dan diberi amanah atas dasar keinginan masyarakat dan bangsanya sendiri sehingga konflik-konflik yang mengarah kepada pembelahan yang dapat mengancam keutuhan masyarakat dan bangsa dapat dieliminasi.

\section{Bibliografi}

Abbas, Abdullah bin. (2008). Tanwîr al-Miqbâs min Tafsîr Ibn 'Abbâs, ed. Muhammad bin Ya'qub al-Fairuzabadi. Beirut: Dar al-Kutub al-Ilmiyah.

'Ali, 'Abdullah Yusuf. (2008).The Holy Qur'an with English Translation \& Selected Commentaries Kuala Lumpur: Saba Islamic Media.

Andopa, A., Hardivizon, H., \& Yunita, N. (2018). The Meaning of Nafs in the Qur'an Based on Quraish Shihab's Interpretation. AJIS: Academic Journal of Islamic Studies, 3(2), 139-162. doi:http://dx.doi.org/10.29240/ajis.v3i2.578

Asyari, Suaidi. (2009). Nalar Politik NU \& Muhammadiyab: Over Crossing Java Sentris. Yogyakarta: LKiS.

Cholif, Muchtar Agus. (2019). Sumpit Gading Damak Ipub Hukum Adat Melayu Jambi (Jambi: Salim Media Indonesia.

Departemen Agama RI. (1984). Al-Quraan dan Terjemahnya (Jakarta: Proyek Pengadaan Kitab Suci Al-Qur'an Departemen Agama RI.

Departemen Agama RI. (1989).Al-Qur'an dan Terjemahnya. Semarang: CV. Toha Putra.

Departemen Agama RI, (2004). Al-Qur'an dan Terjemahnya. Jakarta: CV. Naladana. Jamhari dan Jajang Jahroni (2004). Gerakan Salafi Radikal di Indonesia. Jakarta: RajaGrafindo Persada.

Khalik, Abu Thalib (2014). Pemimpin Non-Muslim dalam Perspektif Ibnu Taimiyah, ANALISIS: Jurnal Studi Keislaman, Vol. 14, No. 1,59-89.

Kurniawan, R., Asmara, M., \& Hardivizon, H. (2021). Arabic Language and the Concept of I'jaz al-Qur'an (Critics to Louwis 'Awad's Thoughts/Bahasa Arab dan Konsep I'jaz al-Qur'an (Kritik Pemikiran Louwis 'Awad). Arabiyatuna : Jurnal Bahasa Arab, 5(1), 161-172. doi:http://dx.doi.org/10.29240/jba.v5i1.2622 
Al-Maraghi. Ahmad Musthafa (1974). Tafsîr al-Marâghî, jilid 2. Beirut: Dar al-Fikr.

Quthb, Sayyid. (2010). Tafsir fi Zhilalil Qur'an, terj. As'ad Yasin, jilid 3. Jakarta: Gema Insani.

Ready, Musholli. (2011). Arus Baru Kecenderungan Penafsiran Kontemporer, Journal of Qur'ân and Hadith Studies, Vol. I, No. I, 85-117.

Saleh, Ahmad Syukri. (2014). Korelasi Ayat dan Surat dalam Perspektif Kontekstualisasi Redaksional al-Qur'an .Ciputat, Jakarta: Refleksi.

------- An Understanding of Some Interpretations of the Qur'an by Textual and Contextual Approaches, seminar proceeding in International Cenference on Qur'an and Hadith Studies, (pp. 333-339). Advances in Social Science, Education and Humanities Research (ASSEHR), Vol. 137. Antlantis Press, 2018.

Shihab, M. Quraish (2006). Tafsir al-Mishbah: Pesan, Kesan dan Keserasian Al-Qur'an, vol. 3 Ciputat, Tangerang: Penerbit Lentera Hati.

- (2014). Membaca Sirah Nabi Mubammad Saw. dalam Sorotan Al-Qur'an dan Hadits-Hadits Shabih. Ciputat, Tangerang: Lentera Hati.

Suryadinata, M. (2015). Kepemimpinan Non-Muslim dalam al-Qur'an: Analisis terhadap Penafsiran Front Pembela Islam (FPI) mengenai Ayat Pemimpin Non-Muslim, Jurnal Ilmu Usbuluddin, Vo. 2 No. 3, 241-250.

Ulum, Bahrul. (2002). "Bodohnya NU" apa "NU Dibodobi"? Jejak Langkah NU Era Reformasi: Menguji Khittah, Meneropong Paradigma Politik. Yogyakarta: Penerbit Ar-Ruгz Press.

Wartini, Atik. (2014). Corak Penafsiran M. Quraish Shihab dalam Tafsir alMisbah”, Hunafa: Jurnal Studia Islamika Vol. 11, No. 1, 109-126.

https://melangun.wordpress.com, "Pemimpin dalam Adat" (19 Maret 2013) diakses 30 April 2021.

https://news.detik.com. "Kontroversi Ahok Soal Al Maidah 51" (7 Oktober 2016).

https://news.detik.com. "MUI Nyatakan Sikap Soal Ucapan Ahok Terkait Al Maidah 51, ini Isinya" (11 Oktober 2016) diakses 5 April 2021.

https://beritasatu.com. "Buya Syafii: Ahok Tidak Menghina Alquran" (7 November 2016) ) diakses 15 April 2021.

https://tirto.id. "Ulama Muhammadiyah Anggap Ahok Sengaja Menodai Agama" (21 Februari 2017) diakses 10 April 2021. 
606 | AL QUDS : Jurnal Studi Alquran dan Hadis vol. 5, no 2, 2021

https://viva.co.id.berita.metro "Saksi Ahli Agama Pihak Ahok Curiga Niat MUI Keluarkan Fatwa” (29 Maret 2017) diakses 20 April 2021.

https://news.detik.com.berita "Sidang Ahok, Ahli Agama Paparkan Pemahaman Al Maidah 51” (29 Maret 2017) diakses 24 April 2021.

https://riauone.com, "Kepemimpinan Ideal dalam Tradisi Melayu" (26 September 2017) diakses 28 Agustus 2021. 